Jurnal Civics: Media Kajian Kewarganegaraan
https://journal.uny.ac.id/index.php/civics/index
$1829-5789$ (print)
$2541-1918$ (online)

\title{
Fungsi partai politik pada kekuasaan eksekutif dan legislatif berdasar pada sistem pemerintahan di Indonesia
}

\author{
Taufikkurrahman ${ }^{\text {a, }}$ * $^{*}$ \\ ${ }^{a}$ Fakultas Ekonomi dan Bisnis Islam, Institut Agama Islam Negeri Madura, Jawa Timur, Indonesia \\ ${ }^{1}$ upik@stainpamekasan.ac.id \\ *korespondensi penulis
}

\begin{tabular}{|c|c|}
\hline \multicolumn{2}{|c|}{ Informasi Artikel } \\
\hline Sejarah artikel: & \\
\hline Diterima & : 09-09-2018 \\
\hline Revisi & : 08-06-2019 \\
\hline Dipublikasikan & : 31-10-2019 \\
\hline
\end{tabular}

Kata kunci:

Fungsi partai politik

Sistem pemerintahan

Pemilu

\begin{abstract}
ABSTRAK
Partai Politik memiliki peran strategis dalam konsolidasi demokrasi setelah Indonesia merdeka khususnya setelah bergulirnya era reformasi. Kehadiran partai politik memiliki fungsi urgen untuk diperhatikan dan diberikan ruang. Salah satu fungsinya adalah pada recruitment politik dalam pengisian jabatan politik pada kekuasaan eksekutif dan legislatif di Indonesia. Fungsi rekrutment dapat dilihat pada sistem pemilu yang diselenggarakan di Indonesia baik pada pemilihan anggota legislatif atau juga dalam pemilihan pasangan Presiden dan Wakil Presiden. Disamping itu terdapat perbedaan fungsi partai secara kelembagaan pada dua kekuasaan tersebut. Pada kekuasaan legislatif, partai politik diberikan ruang yang cukup fundamental dengan diberikannya hak membentuk fraksi sesuai afiliasi politik sehingga akan memudahkan dalam menjalankan fungsi-fungsi lembaga perwakilan. Sedangkan pada kekuasaan eksekutif, sekalipun partai politik tidak diberikan hak yang sama karena indonesia menggunakan sistem pemerintahan presidensial tetapi pengaruh partai politik pada kekuasaan eksekutif dilakukan dalam hubungan ketatanegaraan antara DPR dan Presiden dalam menjalankan wewenang masing-masing.
\end{abstract}

\section{Keywords:}

Functions of political parties Government system Election

\begin{abstract}
Political parties have a strategic role in consolidating democracy after Indonesia's independence, especially after the reform era. The presence of the political party certainly has a vital function to be considered and given space. One of its features is in political recruitment in filling political positions in the executive and legislative powers in Indonesia. The recruitment function can see in the electoral system held in Indonesia both in the legislative elections and also in the election of the pair of Presidents and Vice Presidents. Besides that, there are differences in party functions institutionally in the two powers of eager. In legislative power, political parties are given a reasonably fundamental space by giving them the right to form a faction according to political affiliation so that it will facilitate the carrying out of the functions of representative institutions. While the executive power, even though political parties not give the same rights because Indonesia uses a presidential system of government but the influence of political parties on the executive power is carrying out in constitutional relations between the parliament and the Presiden
\end{abstract}

\section{Copyright $\odot 2019$ Taufikkurrahman}

\section{Pendahuluan}

Indonesia sebagai negara demokrasi terus mengupayakan terwujudnya pemerintahan yang mendukung terciptanya kondisi demokratis tersebut. Sejatinya sejak memasuki masa reformasi 1998, prestasi yang paling luar biasa yang diperoleh selama fase transisi demokratisasi Indonesia terutama diwujudkan melalui serangkaian amandemen konstitusi, sejumlah undang-undang baru dan 
revisi legislatif yang mengatur proses politik baru dan merestrukturisasi institusi negara (Abdulbaki, 2008). Demokrasi yang dianut Indonesia tercermin dalam sistem politik yang diterapkan dimana rakyat sebagai pemegang kedaulatan tertinggi terlibat dalam pengisian jabatan-jabatan politik. Namun demikian, meskipun stabilitas politik dan ekonomi telah dipulihkan, sistem politik baru dapat dicirikan sebagai "demokrasi oligarkis", di mana lembaga-lembaga formal demokrasi sebagian besar dibajak oleh elite oligarki yang mengendalikan konsentrasi besar sumber daya (Fukuoka, 2013; Fukuoka \& Thalang, 2014; Hadiz, 2010; Robison \& Hadiz, 2004; Winters, 2013) .

Untuk memastikan demokrasi berjalan efektif maka disusun instrumen keterlibatan rakyat dalam proses pengisian jabatan politik tersebut. Instrumen yang dimaksud adalah pemilihan umum sebagai perwujudan hak politik seperti hak memilih dan hak dipilih. Hal ini tercantum dalam Undang-Undang Dasar Negara Republik Indonesia Tahun 1945 Bab VII B tentang Pemilihan Umum pasal 22 $\mathrm{E}$ ayat (1) berbunyi "Pemilihan Umum dilaksanakan secara langsung, umum, bebas, rahasia, jujur, dan adil dalam setiap lima tahun sekali". Mudah dipahami maksud "langsung" dalam pemilu adalah rakyat sendiri yang melakukan pemilihan pada beberapa jabatan politik tersebut. Hal demikian ditegaskan dalam ayat (2) pasal 22E yang berbunyi "Pemilihan Umum diselenggarakan untuk memilih anggota DPR, DPD, presiden dan wakil presiden, dan anggota DPRD". Poin penting dalam pemilihan anggota DPR dan DPRD adalah yang menjadi peserta pemilunya adalah partai politik sebagaimana disebutkan dalam ayat (3) pasal $22 \mathrm{E}$ tentang pemilihan umum.

Dari hal tersebut dapat kita lihat bahwa partai politik berperan untuk melakukan rekrutmen anggota yang dapat dipercaya oleh masyarakat untuk dipilih dalam pemilu itu dan menjadi anggota DPR/DPRD yang benarbenar mengemban tugas mandat ini dengan baik sesuai kehendak dan aspirasi masyarakat. Sekalipun partai politik yang menjadi peserta pemilu anggota DPR/DPRD tetapi calon yang berhak duduk di kursi DPR/DPRD adalah mereka yang memperoleh suara terbanyak yang merupakan manifestasi kedaulatan rakyat sesuai sistem pemilu proporsional terbuka yang dianut oleh Indonesia dalam pasal 204 UU Pemilu nomor 7 tahun 2017.

Berbeda dengan partai pemilihan presiden dan wakil presiden. Presiden dan wakil presiden tidak melalui partai politik sebagai peserta pemilunya, melainkan pasangan calon presiden dan wakil presiden, tetapi tetap membutuhkan partai politik sebagai pengusung baik sendiri atau bergabung dengan partai politik yang lain sebagaimana dijelaskan dalam pasal 6 ayat (1) dan (2) UUD 1945. Kemudian dalam UndangUndang nomor 7 tahun 2017 tentang Pemilihan Umum pasal 222 disebutkan bahwa "Partai politik atau gabungan partai politik untuk dapat mengusung pasangan calon presiden dan wakil presiden harus memperoleh kursi $20 \%$ (dua puluh persen) suara sah hasil pemilihan umum anggota DPR atau 25\% (dua puluh lima persen) suara sah secara nasional". Jika tidak ada partai politik yang memenuhi syarat untuk mengusung sendiri karena ada presidensial threshold, maka partai politik dapat berkoalisi dengan partai lain yang memiliki platform atau ideologi yang sama atau memiliki kesamaan misi.

Sekalipun partai politik tidak secara langsung menjadi peserta pemilu tetapi partai politik menjadi syarat dalam pencalonan presiden dan wakil presiden terebut. Sehingga harus kita akui bahwa partai politik tetap memiliki fungsi strategis dalam pengisian jabatan politik khususnya pasangan presiden dan wakil presiden. Dalam kondisi demikian, partai politik dalam pelaksanaan pemilu sekadar sebagai syarat. Keterpilihan para calon murni karena elektabilitas dan kapabilitas calon yang diusung baik calon DPR/DPRD atau Presiden dan Wakil Presiden. Calon anggota DPR/DPRD atau Presiden dan Wakil Presiden yang ingin terpilih dalam pemilu mereka harus mengerahkan berbagai upaya sendiri baik pada saat kampanye atau kemampuan memenuhi janji, visi dan misi dari masingmasing calon. 
Pada calon anggota DPR/DPRD menggunakan sistem proporsional dengan daftar terbuka dengan jumlah calon sesuai jumlah kuota kursi daerah pemilihan. Dalam satu partai politik-pun mereka antar calon akan saling berkompetisi untuk memperoleh suara terbanyak. Bukan lagi memilih partai politik, yang perolehan suaranya nanti akan diberikan kepada calon-calon yang diusungnya seperti pada pemilu 2004 dengan sistem proporsional tertutup, tetapi keterpilihan partai politik dalam pemilu anggota DPR/DPRD adalah berkat keterpilihan calon-calon yang diusungnya.

Partai politik menjadi media/alat penyalur kehendak masyarakat dan pemerintah (Asshiddiqie, 1994). Partai politik juga menjadi bagian tak terpisahkan dari sistem politik demokrasi yang diterapkan di Indonesia karena partai politik menjadi sarana pengisian jabatan-jabatan kekuasaan eksekutif dan kekuasaan legislatif. Namun dalam alam demokrasi Indonesia yang masih seumur jagung, partai-partai politik masih dianggap lemah dan disfungsional dalam mengonsolidasikan demokrasi maka diperlukan penguatan partai politik bertujuan untuk mengubah partai-partai ini menjadi partai kuat yang fungsional untuk mengonsolidasikan demokrasi (Erdmann, 2010). Walaupun demikian, partai politik memiliki hak yang sama dalam pemilihan umum baik pada kekuasaan eksekutif maupun legislatif yaitu mengajukan calon anggota DPR/DPRD untuk kekuasaan legislatif dan mengajukan pasangan calon presiden dan wakil presiden untuk kekuasaan eksekutif.

\section{Metode}

Artikel ini menggunakan metode atau pendekatan perundang-udangan (statute approach), dan pendekatan konseptual (conceptual approach) karena termasuk kajian hukum. Pendekatan UU yang digunakan adalah UU Susunan dan Kedudukan MPR, DPR, DPD, dan DPRD, UU Pemilihan Umum, UU Partai Politik. Sedangkan pendekatan konseptual, penulis telusuri dari berbagai pendapat para pakar untuk mengetahui teori-teori yang dipakai dalam menjabarkan sistem pemerintahan, tata negara, fungsi partai politik dan lain-lain.

\section{Hasil dan Pembahasan}

Membicarakan kekuasaan, tidak luput dari pembahasan konsep trias politica yang digagas oleh Montesquieu. Salah satu ciri negara hukum adalah adanya ciri pembatasan kekuasaan dalam penyelenggaraan kekuasaan negara. Dalam empat ciri klasik negara hukum eropa kontinental yang biasa disebut rechstaat terdapat elemen pembatasan kekuasaan sebagai salah satu ciri pokok negara hukum (Soemantri \& Bintan, 1993). Ide pembatasan kekuasaan itu dianggap mutlak harus ada karena sebelumnya semua fungsi kekuasaan negara terpusat dan terkonsentrasi di tangan satu orang yaitu di tangan raja atau ratu yang memimpin negara secara turun temurun. Bagaimana kekuasaan negara itu dikelola sepenuhnya tergantung pada kehendak pribadi sang raja atau ratu tersebut dengan tanpa melakukan kontrol atau pengawasan supaya kekuasaan itu tidak melakukan penindasan dan menghilangkan hak dan kebebasan rakyat.

Upaya untuk melakukan pembatasan kekuasaan terhadap kekuasaan tidak hanya sebatas pada lahirnya gerakan pemisahan antara kepala negara (raja) dengan pemuka agama (gereja) tetapi lebih pada pemisahan kekuasaan pada internal kekuasaan negara tersebut, yaitu dengan memisahkan kekuasaan itu dari segi fungsi-fungsinya. Dalam hal ini yang sangat dianggap berpengaruh pemikiran yang berkaitan dengan pembatasan dan pemisahan kekuasaan berdasarkan fungsinya yaitu Montesquieu dengan konsep trias politica-nya, yaitu kekuasaan negara dibagi kepada 3 fungsi yaitu eksekutif, legislatif dan yudisial (Asshidiqie, 2010, hal. 282). Pemisahan kekuasaan menurut Montesquieu kemudian disebut sebagai doktrin trias politica (Sulardi, 2012) yang oleh Emmanuel Kant sebenarnya bukan hal yang baru, dikarenakan hal tersebut sudah pernah dikemukakan oleh Aristoteles dan terus dikembangkan oleh John Locke dalam karyanya Two Treaties of Government, kekuasaan negara dikelompokkan menjadi tiga macam yaitu legislatif, eksekutif, dan 
federatif pada tahun 1690 (Wahyudi, 2005, hal. 8).

Menurut Montesquieu, tiga cabang kekuasaan tersebut memiliki fungsi masingmasing. Kekuasaan legislatif sebagai pembuat undang-undang, kekuasaan eksekutif yang melaksanakan atau menerapkan undangundang, dan kekuasaan yudisial untuk menghakimi (Asshiddiqie, 2009, hal. 238).

Untuk memetakan definisi separation of power, Marshall (Asshidiqie, 2010, hal. 289290) memberikan ciri-ciri pemisahan kekuasaan kedalam lima hal, yakni pertama, doktrin pemisahan kekuasaan itu bersifat membedakan fungsi-fungsi legislatif, eksekutif, dan yudisial, yang dalam pelaksanaannya aturan tersebut untuk menyelesaikan konflik atau perselisihan. Kedua, doktrin pemisahan kekuasaan menghendaki orang yang sedang berkuasa pada salah satu cabang kekuasaan tidak melakukan rangkap jabatan walau dalam sistem pemerintahan parlementer itu tak pernah konsisten dilaksanakan. Ketiga, doktrin pemisahan kekuasaan juga menentukan bahwa masing-masing cabang kekuasaan tidak boleh saling campur aduk terhadap kegiatan cabang kekuasaan lain. Sehingga masing-masing cabang kekuasaan dapat independen. Keempat, dalam doktrin pemisahan kekuasaan, harus terdapat check and balances, setiap cabang kekuasaan harus melakukan pengawasan untuk menjaga keseimbangan antar kekuasaan negara. Kelima, semua cabang kekuasaan memiliki kesetaraan dan memiliki kedudukan yang sederajat sehingga dapat melaksanakan koordinasi dengan baik.

Undang-Undang Dasar Negara Republik Indonesia tahun 1945 (UUD 1945) sendiri sudah mengatur tentang sistem ketatanegaraan Indonesia sebagai dasar dalam penyelenggaraan kekuasaan negara. Pengaturan ketatanegaraan tersebut tidak lain untuk memberikan batasan kewenangan kepada masing-masing cabang kekuasaan yang ada supaya cita-cita negara dapat terwujud dengan baik sesuai keinginan dari para pendiri bangsa.

Jika lihat sistem ketatanegaraan indonesia, indonesia walaupun tidak secara eksplisit mengatakan sebagai negara yang menerapkan pemisahan dan pembagian kekuasaan ala Montesquieu, tetapi jika dilihat dari struktur ketatanegaraan dalam UUD 1945 dapat secara gamblang dipahami bahwa indonesia menerapkan pemisahan dan pembagian kekuasaan (trias politica) seperti yang dibahas pada bagian terdahulu. Hanya saja pemisahan dan pembagian kekuasaan yang digunakan di Indonesia tidak seketat pandangan Montesquieu bahwa masingmasing cabang kekuasaan berdiri sendirisendiri melainkan menggunakan asas checks and balances.

Pada cabang kekuasaan eksekutif misalnya, negara memberikan kewenangan kepada presiden dan wakil presiden yang bertugas untuk melaksanakan pemerintahan (melaksanakan undang-undang). Pada cabang legislatif, negara membentuk badan perwakilan yang diberi nama dewan perwakilan rakyat yang dipilih berdasarkan partai politik dan dewan perwakilan daerah yang dipilih berdasarkan distrik. Pada kekuasaan yudisial diselenggarakan oleh mahkamah agung (dan badan peradilan di bawahnya meliputi lingkungan peradilan umum, peradilan agama, peradilan tata usaha negara, dan peradilan militer) dan oleh sebuah mahkamah konstitusi untuk memeriksa, mengadili dan memutus perkara pada tingkat pertama dan terakhir yang putusannya bersifat final dan mengikat. Semua cabang kekuasan tersebut, setara atau sejajar dengan menghilangkan kekuasaan negara yang lebih tinggi dari lembaga negara lainnya. Yang artinya pemisahan dan pembagian kekuasaan di Indonesia dilaksanakan secara seimbang dan saling mengontrol satu sama lain

Berhubung Indonesia menggunakan asas checks and balances dalam sistem ketatanegaraan Indonesia, maka masingmasing kekuasaan negara tidak memiliki kewenangan yang mandiri, artinya terdapat kewenangan-kewenangan yang dilakukan oleh lembaga lain sebagai pengawas atau penyeimbang. DPR misalkan dalam pembuatan undang-undang tidak bisa melakukan sendiri sekalipun kekuasaan membentuk undang-undang itu adalah kewenangan DPR, namun masih 
membutuhkan Presiden untuk memperoleh persetujuan bersama.

Presiden sebagai kepala negara dan kepala pemerintahan diberi fungsi melaksanakan undang-undang. Misalnya hak presiden dalam menyatakan perang, menjalin hubungan internasional dengan negara lain, memberikan amnesti dan abolisi masih membutuhkan persetujuan anggota DPR. Presiden juga butuh pertimbangan mahkamah agung dalam memberikan grasi dan rehabilitasi.

Demikian pula pada kekuasaan mahkamah agung dan mahkamah konstitusi. Dua lembaga negara tersebut masih butuh persetujuan DPR dan Presiden dalam pengusulan dan pengangkatan para hakimnya. Semua kewenangan yang dimiliki oleh masing-masing cabang kekuasaan negara di Indonesia masih membutuhkan peran lembaga lainnya walaupun bukan sebagai bentuk intervensi hanya sebatas pada pengawasan. Kekuasaan eksekutif biasanya dipegang oleh badan eksekutif. Di negaranegara demokratis badan eksekutif biasanya terdiri atas kepala negara seperti raja atau presiden dan sebagai kepala pemerintahan (Budiarjo, 2008, hal. 295). Pembentukan kepala negara berkaitan dengan bentuk pemerintahan. Sedangkan kepala pemerintahan berkaitan sistem pemerintahan.

Kadang kala banyak orang yang salah tempat dalam memberikan definisi yang benar terhadap kata sistem pemerintahan dan bentuk pemerintahan. Jika kita lihat dalam buku-buku Ilmu Negara, dua kata tersebut memiliki arti yang sangat berbeda walau masih dalam koridor pemerintahan. Bentuk pemerintahan adalah suatu sistem mengenai pengangkatan kepala negara. Jika kepada negara berdasarkan keturunan maka negara tersebut tergolong bentuk pemerintahan Monarki. Jika kepala negara dipilih dalam pemilihan umum untuk masa jabatan tertentu disebut dengan bentuk pemerintahan republik. Atas klasifikasi tersebut maka bentuk pemerintahan memang dibagi kepada dua jenis yaitu monarki dan republik (Isra, 2010, hal. 23).

Menurut Mahfud-MD (Mahfud-MD, dipahami sebagai suatu hubungan tata kerja antar lembaga-lembaga negara." Selain dua pendapat tersebut, Ranawijaya (Isra, 2010, hal. 24) mengenengahkan bahwa "sistem pemerintahan merupakan sistem hubungan antara eksekutif dan legislatif." Dari semua definisi yang dikemukakan oleh para ahli dapat ditarik benang merah bahwa sistem pemerintahan dapat diartikan yaitu hubungan ketatanegaraan antara kekuasaan eksekutif dan legislatif.

Secara praktik, sistem pemerintahan yang banyak dikembangkan oleh beberapa negara yang menjadi rujukan ketatanegaraan di seluruh dunia adalah sistem presidensial, parlementer, dan campuran. Maka dalam penelitian ini, sistem pemerintahan yang akan dibahas fokus pada dua jenis saja yaitu sistem pemerintahan presidensial dan sistem pemerintahan parlementer karena dua sistem tersebut pernah dipakai dalam ketatanegaraan Indonesia sejak merdeka pada tahun 1945 sampai saat ini. Dalam hal sistem pemerintahan parlementer, objek utama kajian ini terletak pada parlemen (lembaga perwakilan). Hal ini tidak lain karena berkaitan dengan kontestasi pemilihan umum para calon anggota badan perwakilan yang kelak akan saling berebut suara terbanyak untuk memperoleh hak sebagai pembentuk kabinet. Orang atau partai politik yang berhak membentuk kabinet adalah orang atau partai yang mendapat dukungan mayoritas dari pemilik suara.

Sistem pemerintahan presidensial tidak dapat dipisahkan dari sistem pemerintahan Amerika Serikat. Amerika Serikat tidak sekadar menjadi tempat kelahiran sistem presidensial ini, tetapi juga menjadi prototipe ideal dalam implementasi konsep presidensial ini (Isra, 2010, hal. 31). Berbeda dengan sejarah sistem parlementer, sistem presidensial tidak dibangun melalui proses evolusi yang lambat dan panjang. Kelahiran sistem pemerintahan presidensial tidak dapat dilepaskan dari perjuangan Amerika Serikat menentang dan melepaskan diri dari kolonial Inggris serta sejarah singkat pembentukan konstitusi Amerika Serikat (Ranadireksa, 2010, hal. 127).

2001, hal. 83), "sistem Pemerintahan 
Partai politik telah menjadi ciri penting dalam sebuah politik modern karena memiliki fungsi yang strategis. Para ahli pun banyak yang merumuskan fungsi-fungsi dari partai politik. Fungsi utama dari partai politik adalah mencari kekuasaan, mendapatkan kekuasaan dan mempertahankannya. Cara partai politik untuk memperoleh kekuasaan tersebut ialah dengan berpartisipasi dalam pemilihan umum. Untuk melaksanakan fungsi tersebut partai politik melakukan tiga hal yang umumnya dilakukan oleh partai politik yaitu menyeleksi calon-calon, setelah calon-calon mereka terpilih selanjutnya ialah melakukan kampanye, setelah kampanye dilakukan dan calon terpilih dalam pemilihan umum selanjutnya yang dilakukan oleh partai politik ialah melaksanakan fungsi pemerintahan (legislatif ataupun eksekutif).

Secara garis besar, Firmanzah (2011, hal. 70) menyebutkan bahwa "peran dan fungsi partai politik dibedakan menjadi dua, yaitu fungsi internal dan fungsi eksternal." Dalam fungsi internal, partai politik berperan dalam pembinaan, pendidikan, pembekalan, dan pengaderan bagi anggota partai politik demi langgengnya ideologi politik yang menjadi latar belakang pendirian partai politik tersebut. Sedangkan dalam fungsi eksternal peranan partai politik terkait dengan ruang lingkup yang lebih luas yakni masyarakat, bangsa, dan negara. Hal ini karena partai politik juga mempunyai tanggungjawab konstitusional, moral, dan etika untuk membawa kondisi, dan situasi masyarakat menjadi lebih baik (Firmanzah, 2011, hlm. 70). Secara lebih rinci Budiarjo (2008) menyebutkan bahwa fungsi partai politik adalah sarana komunikasi politik, sarana sosialisasi politik, rekrutmen politik, pengatur konflik.

Bila rezim dalam sistem politik mengakui adanya kompetisi antar partai politik atau menindas kesempatan bersaing antar politik, maka yang muncul adalah sistem satu partai. Bentuk sistem partai tunggal adalah dimana di negara tersebut hanya dikuasai atau didominasi oleh satu partai walaupun masih ada partai lain namun tidak memiliki peran yang signifikan. Sistem partai tunggal totaliter yaitu, partai tersebut benar-benar dijadikan alat oleh penguasa untuk mengendalikan kehidupan masyarakat secara penuh. Jika partai tunggal otoriter, berarti hanya ada satu partai besar yang digunakan penguasa sebagai alat memobilisasi rakyat dan mengesahkan kekuasaan, sedangkan yang lain hanya dibatasi ruang geraknya oleh penguasa.

Sistem dwi partai tidak jauh beda dengan sistem partai tunggal dominan, dimana di negara tersebut dibuka ruang kepada beberapa partai politik untuk berkompetisi dalam pemilu, tetapi partai yang memperoleh suara terbanyak selalu dikuasai oleh dua partai, sedangkan yang lain harus bergabung kepada dua partai tersebut. Sedangkan sistem multi partai adalah tidak adanya satu partai yang mendominasi perolehan suara, terdapat beberapa partai yang memiliki suara secara seimbang. Partai-partai politik yang beredar, merupakan representasi dari ideologi dan kehidupan rakyat di negara tersebut. Sistem multi partai ini, memungkinkan sekali kepada partai-partai yang memiliki kesamaan platform dan ideologi yang berdekatan untuk melakukan koalisi dalam membentuk pemerintahan.

Partai politik memiliki peran signifikan dalam perkembangan sistem politik di suatu negara terutama pada negara-negara yang menggunakan sistem demokrasi sebagai bagian dalam kehidupan bernegara. Atas peran besar tersebut, eksistensi partai politik harus dijamin keberadaannya oleh konstitusi sebagai pengakuan hak berkumpul dan hak berserikat sesuai kehendak masing-masingmasing warga negara. Pentingnya partai politik itu karena partai menjadi alat penyambung lidah kepentingan-kepentingan individu terhadap kepentingan nasional dan penguasa. Dengan adanya partai politik itu, kehendak individu dapat dimanifestasikan menjadi program-program pemerintahan. Dengan hal tersebut harus kita akui, bahwa partai politik memiliki pengaruh dan fungsi yang sangat pokok terhadap sistem pemerintahan khususnya di Indonesia.

Kehadiran partai politik tersebut membawa angin segar terhadap tumbuhnya sistem politik yang baik dan terwujudnya pemerintahan yang dapat memenuhi cita-cita bangsa Indonesia sebagaimana tercantum 
dalam pembukaan UUD 1945 yaitu mewujudkan kesejahteraan umum. Dengan adanya pemilu dan terpilihnya beberapa orang perwakilan rakyat akan membawa pengaruh terhadap kekuasaan itu sendiri, baik pengaruh terhadap kekuasaan Eksekutif ataupun terhadap kekuasaan legislatif (berdasarkan konsep trias politica Montesquieu).

Dalam kontestasi pemilu, partai politik saling beradu tajam dalam meraih dukungan rakyat dengan janji-janji kampanye sesuai platform politik masing-masing sehingga kursi yang diperolehnya paling tidak di atas dari ketentuan Parliamentary Threshold sebesar 4\%. Ketika perolehan suara yang sudah dikonversi menjadi kursi sampai pada ambang batas minimal tersebut, partai politik baru akan berupaya untuk mewujudkan dan menggalakkan cita-cita partai politiknya dalam segala tugas dan wewenang di lembaga perwakilan rakyat tersebut.

Dalam pasal 20A UUD 1945 jo. Pasal 69 ayat (1) UU 13 Tahun 2019 tentang Perubahan Ketiga Atas UU 17 tahun 2014 tentang MD3, menyebutkan DPR memiliki fungsi legislasi, anggaran dan pengawasan. Ketiga fungsi tersebut dijalankan dalam kerangka representasi kedaulatan rakyat dan untuk mendukung upaya pemerintah dalam melaksanakan politik luar negeri (Pasal 69 ayat (2)). Dilanjutkan dengan pasal 70 bahwa fungsi-fungsi tersebut merupakan perwujudan dari kewenangan DPR sebagai pemegang kekuasaan dalam membentuk UndangUndang. Fungsi legislasi merupakan fungsi utama dari DPR itu sendiri. Bahwa DPR selaku pemegang kekuasaan dalam membentuk undang-undang. Bahkan dalam menjalankan fungsi tersebut, setiap anggota DPR berhak untuk mengusulkan RUU (pasal 21 UUD 1945). Hanya saja dalam pembentukan undang-undang itu sekalipun kekuasaannya berada di tangan DPR tidak sepenuhnya dapat dilakukan oleh DPR sendiri melainkan masih membutuhkan pembahasan dan persetujuan bersama dengan presiden selaku pemegang kekuasaan eksekutif. Hal ini ditegaskan dalam pasal 20 ayat (2) UUD 1945 bahwa setiap RUU dibahas bersama dengan presiden untuk mendapatkan persetujuan bersama. Sekalipun RUU tersebut inisiatif pengusulannya berasal dari anggota DPR sendiri.

Dalam proses pembentukan suatu undang-undang yang akan dijadikan dasar hukum pemerintah dalam menjalankan pemerintahan sering kali terjadi ketegangan dan ketidaksamaan kehendak antar masingmasing lembaga negara (presiden dan DPR) bahkan ketidaksamaan bisa juga muncul antar anggota DPR sendiri karena perbedaan fraksi. UUD kemudian memberikan suatu penjelasan bahwa jika terjadi kesepakatan dalam pembahasan RUU untuk mendapatkan persetujuan bersama, maka RUU itu tidak boleh lagi dibahas di masa persidangan DPR itu lagi (pasal 20 ayat (3) UUD 1945).

Lewat kewenangan legislasinya, DPR dan pemerintah kemudian menetapkan Presidential Threshold dalam pencalonan pasangan calon presiden dan wakil presiden sebesar 20\% (dua puluh persen) perolehan kursi DPR dari partai politik pengusung atau memperoleh $25 \%$ (dua puluh lima persen) suara sah nasional pada pemilu tahun sebelumnya sebagaimana dalam pasal 222 UU Pemilu. Sekalipun pasal ini telah diuji materi pada Mahkamah Konstitusi (MK) oleh beberapa orang, namun MK berpendapat dan memutuskan sebagaimana Putusan Mk nomor 33/PUU-XVI/2018 bahwa adanya persyaratan Presidential Threshold adalah murni resultante dari pembuat udang-undang sekalipun Presidential Threshold tersebut tidak tercantum dalam UUD 1945.

Partai politik memiliki perbedaan fungsi antara negara yang menggunakan sistem pemerintahan Parlementer dan Presidensial. Perbedaan fungsi tersebut dapat dilihat dalam pemilihan kepala pemerintahannya. Jika pada sistem pemerintahan parlementer, yang terpilih menjadi kepada pemerintahan adalah pimpinan Partai Politik pemenang pemilu legislatif baik dan biasanya menggunakan sistem dwi partai. Sehingga pihak yang kalah (Partai yang kalah) akan secara otomatis menjadi oposisi.

Secara kelembagaan negara di Indonesia tampaknya sudah termasuk pada ciri-ciri konsep pemisahan kekuasaan berdasarkan UUD 1945. Hal itu terlihat dari urusan masing-masing kekuasaan negara sudah

Jurnal Civics: Media Kajian Kewarganegaraan |151 
dibagi kepada lembaga negara yang berbedabeda. Kekuasaan eksekutif diberikan kepada Presiden sebagai kepala negara dan kepala pemerintahan. Kekuasaan legislatif diberikan kepada DPR. Kekuasaan Yudikatif diberikan kepada Mahkamah Agung dan Mahkamah Konstitusi. Hanya saja, secara tugas dan wewenang masih terdapat unsur saling terkait satu sama lain dan tidak bisa berdiri sendiri. Terdapat beberapa tugas dan wewenang Presiden bersinggungan dengan DPR sebagai lembaga perwakilan (kekuasaan legislatif dan ada wewenang yang juga berkaitan dengan bidang yudikatif.

\section{Simpulan}

Terdapat beberapa macam fungsi partai politik diantaranya yaitu fungsi rekrutmen politik dalam pengisian jabatan politik khususnya pada kekuasaan legislatif dan kekuasaan eksekutif. Fungsi rekrutmen ini pada kekuasaan legislatif diterapkan dalam pelaksanaan pemilihan umum untuk memilih anggota DPR/DPRD dan peran-peran yang secara kelembagaan pada tubuh DPR/DPRD diberi ruang oleh undang-undang untuk mengambil peran dalam optimalisasi fungsi, tugas dan wewenang DPR berupa pembentukan fraksi sebagai wadah afiliasi partai politik dalam menjalankan fungsi legislasi, fungsi anggaran dan fungsi pengawasan DPR. Pembentukan fraksi yang berafiliasi partai politik merupakan kerangka logis karena partai politik sebagai peserta pemilu itu sendiri. Sedangkan fungsi partai politik pada kekuasaan eksekutif khusus pada rekrutmen politik, partai politik berperan dalam pengusulan pasangan calon presiden dan wakil presiden sebagai peserta pemilihan umum untuk memilih presiden dan wakil presiden. Sedangkan pada pada kelembagaannya, berbeda dengan fungsi kelembagaan di DPR yang terdapat fraksi. Partai politik tidak dapat mempengaruhi secara kelembagaan tetapi memiliki pengaruh langsung tetapi pengaruh tidak langsung lewat bertemunya beberapa kewenangan yang dimiliki presiden dan DPR berupa dalam pembentukan undang-undang dimana Presiden berhak mengajukan RUU dan membahas bersama dengan DPR untuk mendapatkan persetujuan dalam pembentukan undang-undang. Partai politik memang sebagai instrumen demokrasi, tetapi tidak semua kekuasaan negara dapat dimasuki oleh partai politik bahkan pada kekuasaan eksekutif sekalipun paling hanya sebatas pada pengusungan pasangan calon presiden dan wakil presiden. Berbeda dengan fungsi partai politik yang ada di DPR, yang sepenuhnya dikendalikan oleh partai politik dalam pengambilan keputusan anggota-anggotanya melalui fraksi di DPR sekalipun bukan sebagai alat kelengkapan DPR. Perbedaannya terlatak pada pelembagaan fungsi secara institusional

\section{Referensi}

Abdulbaki, L. (2008). Democratisation in Indonesia: from transition to consolidation. Asian Journal of Political Science, $\quad 16(2), \quad 151-172$. https://doi.org/10.1080/0218537080220 4099

Asshiddiqie, J. (1994). Gagasan kedaulatan rakyat dalam konstitusi dan pelaksanaannya di Indonesia: pergeseran keseimbangan antara individualisme dan kolektivismme dalam kebijakan demokrasi politik dan demokrasi ekonomi selama tiga masa demokrasi, 1945-1980-an. Jakarta: Ichtiar Baru Van Hoeve.

Asshiddiqie, J. (2009). Komentar atas Undang-Undang Dasar Negara Republik Indonesia Tahun 1945. Jakarta: Sinar Grafika.

Asshidiqie, J. (2010). Pengantar ilmu hukum tata negara. Jakarta: Raja Grafindo.

Budiarjo, M. (2008). Dasar-dasar ilmu politik. Jakarta: Gramedia Pustaka Utama.

Erdmann, G. (2010). Political party assistance and political party research: Towards a closer encounter? Democratization, 17(6), 1275-1296. https://doi.org/10.1080/13510347.2010. 520551

Firmanzah. (2011). Mengelola partai politik: komunikasi dan positioning, ideologi politik dan era demokrasi (edisi revisi). Jakarta: Yayasan Obor Indonesia. 
Fukuoka, Y. (2013). Oligarchy and democracy in post-suharto indonesia. Political Studies Review, 11(1), 52-64. https://doi.org/10.1111/j.14789302.2012.00286.x

Fukuoka, Y., \& Thalang, C. na. (2014). The legislative and presidential elections in Indonesia in 2014. Electoral Studies, 36, 210-239.

https://doi.org/10.1016/j.electstud.2014. 09.007

Hadiz, V. (2010). Localising power in postauthoritarian Indonesia: A Southeast Asia perspective. Stanford University Press.

Isra, S. (2010). Pergeseran fungsi legislasi: menguatnya model legislasi parlementer dalam sistem presidensial Indonesia. Jakarta: Raja Grafindo Persada.

Mahfud-MD, M. (2001). Dasar dan struktur ketatanegaraan Indonesia. Jakarta: Rineka Cipta.

Ranadireksa, H. (2010). Visi bernegara: arsitektur konstitusi demokratik. Bandung: Fukus Media.

Robison, R., \& Hadiz, V. (2004). Reorganising power in Indonesia: The politics of oligarchy in an age of markets. Routledge.

Soemantri, S., \& Bintan, R. S. (1993). Ketatanegaraan Indonesia dalam kehidupan politik Indonesia-30 tahun kembali ke UUD 1945. Jakarta: Pustaka Sinar Harapan.

Sulardi. (2012). Rekonstruksi sistem pemerintahan presidensiil berdasar Undang- Undang Dasar 1945 menuju sistem pemerintahan presidensiil murni. Jurnal Konstitusi, 9(3), 515-530.

Wahyudi, A. (2005). Doktrin pemisahan kekuasaan: akar filsafat dan praktik. Jurnal Jentera, 8(3).

Winters, J. A. (2013). Oligarchy and democracy in Indonesia. Indonesia, (96), 11-33. 